\title{
Os debates pelo fim do tráfico no periódico o Philantropo (1849-1852) e a formação do povo: doenças, raça e escravidão ${ }^{1}$
}

The debate on the end of the slave trade in the periodical O Philantropo (1849-1852) and the formation of the people:

illnesses, race and slavery

Kaori Kodama*

\section{Resumo}

O propósito deste artigo é investigar a atuação do jornal O Philantropo (18491852), bem como da "Sociedade contra o Tráfico de Africanos e Promotora da Colonisação e da Civilização dos Indígenas", que sustentou o jornal. Procura-se atentar para a especificidade dos segmentos presentes na Sociedade em relação ao projeto de fim do tráfico, no momento em que ocorriam os debates no Parlamento. No jornal, a bandeira antitráfico combinava em suas propostas a defesa da mão-de-obra livre e um nacionalismo que muitas vezes lançava mão de argumentos racialistas. Interessa-nos, assim, destacar aspectos do debate da Sociedade através de um exame do perfil de seus sócios e na articulação que apresentaram entre as questões da colonização e da formação do povo, através dos temas da raça, das doenças e da escravidão.

Palavras-chave: tráfico de escravos; raça; nação.

\section{Abstract}

This paper aims at investigating the newspaper O Philantropo (1849-1852) and the Society against the Slave Trade and for the Colonization and Civilization of the Indians which supported it. It focuses on the specific roles of the Society's members in the movement for ending the slave trade, when the discussion for its suppression was taking place in Parliament. In the newspaper, ranged under the banner of the defense against the slave trade, could also be found the support for a free labor force and a nationalism which frequently made use of racialist arguments. It attempts to detach some aspects of the debate of the Society by examining the profile of its members as well as by articulating the problem of colonization with the formation of the nation through the issues of race, diseases and slavery.

Keywords: slave trade; race; nation.

\footnotetext{
* Doutora em História, PUC-Rio, Pesquisadora Visitante da Casa de Oswaldo Cruz/Fiocruz Av. Brasil, 4036 - sala 403 - Manguinhos. 21040-361 Rio de Janeiro - RJ - Brasil. kaori@coc. fiocruz.br.
} 
No calor dos debates sobre o fim do tráfico intercontinental de escravos no Império do Brasil, formava-se na cidade do Rio de Janeiro o jornal O Philantropo, que passaria a circular desde 6 de abril de 1849. Já se anunciava no editorial do primeiro número que o objetivo d'O Philantropo era o de "combater a escravidão doméstica entre nós, demonstrar seus negros males, e apresentar os mais seguros meios de a extinguir, e prevenir seus funestos resultados" (O Philantropo, 6.04.1849). O jornal publicado todas as sextas-feiras seria impresso na tipografia "Filantrópica", localizada na rua do Lavradio, e se dividia em três partes, "Seção humanitária", "Seção científica" e "Seção literária", dissertando sobre os diversos males da escravidão e de seus principais agentes - os "traficantes de carne humana".

A atuação desse jornal foi comentada por diversos trabalhos que trataram da história da imprensa no Brasil, do fim da escravidão e do movimento antiescravista em meados do século XIX. ${ }^{2}$ Em particular, fizeram a ela referência autores que analisaram as ações inglesas para financiar a propaganda contra o tráfico no Brasil. Para Leslie Bethell, por exemplo, o aparecimento do jornal era sintoma de uma mudança da opinião pública sobre a questão do tráfico em 1849, quando diversos jornais, tais como O Philantropo, O Monarchista, O Contemporaneo, O Correio Mercantil e O Grito Nacional surgiam ao lado de outros periódicos locais para criticar o tráfico e também a escravidão. ${ }^{3}$ Alguns desses jornais receberam financiamento do Fundo de Serviço Secreto britânico. David Eltis, citando as mesmas correspondências de Bethell entre o representante britânico James Hudson e lord Palmerston que revelam tais estratégias do governo inglês, afirma que $O$ Philantropo se estabelecera com a ajuda do Fundo através de um dos beneficiados, Leopoldo Augusto da Câmara Lima, que era também um dos fundadores do jornal. ${ }^{4}$ Mais recentemente, o semanário foi comentado em trabalhos que procuraram investigar a questão nacional junto à questão da raça e da mestiçagem através da imprensa, nos anos de consolidação do Estado imperial. ${ }^{5}$

No entanto, as relações entre o jornal e os setores da sociedade envolvidos, bem como o teor dos debates encaminhados por essa imprensa, foram até o momento pouco investigados em si mesmos. Parte dessa menor atenção a tais aspectos pode ser tomada pela premissa de que sua contribuição não teria sido efetiva para a consecução do projeto que proibia o comércio transatlântico de escravos. Outro motivo, ligado a este primeiro, poderia ser extraído do caráter político subjacente ao jornal, devido aos elos com os grupos de oposição ao governo de muitos de seus participantes, direta ou indiretamente. Assim, a função d'O Philantropo teria sido cumprida após o fim do embate 
interno ao grupo liberal despojado do poder em 1848 pelos saquaremas que assumiram a direção do governo, no seio do debate que impôs a lei Eusébio de Queirós. Sua circulação foi encerrada em 1852, quando a repressão ao tráfico transatlântico parecia surtir efeito e a escravidão retomava seu rumo através do tráfico interno.

De fato, pode-se afirmar que o curto período de sua existência está relacionado ao apaziguamento da questão do fim do tráfico e da continuação da escravidão, bem como à derrota política dos segmentos que elevariam sua voz através do periódico. A fundação da "Sociedade contra o Tráfico de Africanos e a Favor da Civilização dos Indígenas”, em 1850, da qual o jornal passaria a ser órgão, não deixaria de representar uma boa parcela dos atores políticos ligados ao Partido Liberal e que defenderam a colonização, criticando o sistema de trabalho escravo.

Entretanto, apesar da existência efêmera - de três anos - do jornal, verifica-se a sobrevida da "Sociedade contra o Tráfico", cujas atividades foram mantidas até ao menos 1858. Segundo o Almanack Laemmert, em seu primeiro ano de funcionamento, a Sociedade conseguira agregar mais de trezentos sócios efetivos. ${ }^{6}$ Ao recuperarmos a trajetória de alguns desses participantes, bem como as redes nas quais estavam inseridos alguns deles, pode-se melhor conhecer como se dava o encaminhamento dos debates sobre a escravidão no seio da sociedade urbana do Rio de Janeiro, em sua lógica e em suas contradições. Acreditamos que um conhecimento mais situado dos agentes do jornal pode auxiliar a entrever parcelas da sociedade imperial que repercutiram determinados discursos sobre a escravidão, colonização e que, sobretudo, direcionaram a questão da "formação do povo". Sobre este aspecto, diversos textos do jornal não deixariam de imprimir argumentos importantes que sinalizam para as releituras racialistas posteriores. Para isso, vamos nos deter em particular sobre os temas das doenças de escravos, da raça e da nação naquele momento. Mas antes, prosseguiremos com as temáticas centrais d'O Philantropo, o fim do tráfico e a questão da colonização.

\section{O FIM DO TRÁFICO E A QUESTÃo DA COLONIZAÇÃo}

Certamente, o contexto no qual O Philantropo foi lançado alimentou-se das diversas questões que giravam em torno da cessação do comércio transatlântico, e que tinham por propulsores a atuação inglesa, na caça aos navios carregados de escravos em mares brasileiros e na sua promoção de correntes internas contrárias ao tráfico; o incremento da entrada de africanos naqueles 
anos e o medo das rebeliões escravas; além das disputas no seio do governo, com a saída dos liberais desde setembro de 1848.7 Aquele momento indica, ainda, a precipitação de uma discussão de longa data: a da colonização. Essa questão, não obstante surgir nas falas de ministros e presidentes de província ao longo dos períodos após a Independência, adquire novos rumos com o fim do tráfico. Sobretudo, a partir das discussões que se adensam durante a década de 1840, é possível observar que a questão da colonização passava a incorporar com mais ênfase o problema da formação do povo.

Durante a primeira metade do século XIX, os textos que discutiam a necessidade de substituição do trabalho escravo pela mão-de-obra livre nem sempre se vinculavam com os projetos que propunham ações mais efetivas para o término da escravidão. ${ }^{8}$ Da mesma maneira como os projetos de colonização e introdução do trabalho livre não significavam a defesa radical do fim do trabalho escravo, encontravam-se as mais variadas propostas para a consecução da colonização no Brasil. Elas poderiam incluir desde a chamada de europeus, passando pelo uso do trabalho indígena à colonização por asiáticos, e em raras ocasiões, por africanos, como sugeriria José Elói Pessoa na Memoria sobre a escravatura e projecto de colonisação dos europeus e pretos da África no Imperio do Brazil. ${ }^{9}$ Raimundo José da Cunha Mattos, que já defendia o resguardo da soberania nacional e a condução do negócio negreiro pelo Estado brasileiro contra a Inglaterra em 1827, indicava em 1837 os meios para uma colonização incluindo europeus e também asiáticos. Nesse sentido, Cunha Matos não era contrário ao projeto de João Antonio de Sampaio Vianna, publicado também em 1837, intitulado Ensaio sobre a utilidade da importação de Chinas para colonização do Brazil, que era oferecido ao Diretório de Colonização da Bahia. Ao longo desse tempo, a questão da mão-de-obra livre foi pontuada no debate de poucos letrados e a execução de projetos de colonização observada em esparsos casos bem-sucedidos, como o da colônia de São Leopoldo.

No final da década de 1840, a imprensa passa a tratar com mais intensidade da questão do fim do tráfico, aliando ao problema da escravidão a necessidade de se promover a colonização. Já no decorrer da década, jornais como Minerva brasiliense e O Guanabara, cujos redatores - entre os quais figuras como Torres Homem - defendiam o modo gradual de substituição de mãode-obra escrava pela livre, e debatiam, em diversos escritos, a colonização, concedendo ao assunto um espaço razoável. A presença do tema da colonização na imprensa, ligando-o em muitos casos ao fim da escravidão, acompanha o movimento dentro do governo para a promoção da colonização, com o 
início dos debates que levaria tanto à lei de Terras de 1850 como ao Regulamento das Missões, em 1845, e que previa a "civilização e catequese" dos índios como meio de colonização "interna", como então se falava, juntamente com a chamada de imigrantes estrangeiros.

No momento da cessação do comércio de escravos, alguns jornais vieram a público debater o tráfico, discutindo em paralelo a questão da colonização. Não se crê, contudo, que tal discussão, como ela surgia, estava associada necessariamente ao vislumbre do fim da escravidão ou ao seu desejo. Muitas vezes, elas apareciam como uma faceta da disputa política que tomava lugar naqueles anos. O jornal O Monarchista, que começou a circular em 1848, estamparia em suas epígrafes uma "Fala do Trono" daquele mesmo ano, na qual se atentava para a substituição de braços, atraindo colonos, e um discurso de Eusébio de Queirós de 1842, apoiando a extinção do "tráfico desumano". Todavia, ao se olhar mais de perto esse jornal, percebe-se que O Monarchista era um periódico lançado para combater os liberais, sobrepondo a eles a discussão sobre o fim do tráfico, buscando assim tirar-lhes a causa. Mesmo o fim do tráfico não era de todo defendida pelo jornal, que afirmara - segundo uma nota do seu crítico, O Philantropo - a possibilidade de extinção gradativa da escravidão sem que cessasse o tráfico. ${ }^{10}$ Outros tomavam assumidamente a posição dos liberais, como no caso do jornal $O$ Americano. Em 1849, a folha $A$ Verdade anunciava a guerra aos "contrabandistas de carne humana", declarando que denunciaria os pontos de desembarque de escravos, indicando também os navios que se empregavam no tráfico "para que as autoridades não durmam como até agora tem acontecido" (A Verdade, 4.05.1849). O apoio inglês a tais investidas viria ao encontro do antilusitanismo que envolvia grande parte dos escritos na imprensa. É certo que em fins da década de 1840, a imagem do traficante negreiro já era associada ao inescrupuloso e imoral negociante de origem portuguesa. É assim que um jornal menos voltado para o debate político, como O Beija-Flor, revelava a imagem do negreiro em suas páginas, no "conto romântico" de Joaquim Norberto de Sousa e Silva, "O testamento falso". O conto, que apareceu em 1849, tratava do contrabandista português Manoel Luiz de Faria, que se casa com a bela Margarida, filha de um respeitável brasileiro chamado Anselmo Rodrigues. Manoel é caracterizado como "negreiro, contrabandista, ambicioso de riqueza e ávido de todas as honras criadas pela sociedade, e por ele prostituídas aos sacerdotes de Pluto". Não obstante, no conto, o inescrupuloso homem tornava-se ainda mais rico com uma herança surrupiada de seu rival e se casava com Margarida, separando-a de seu amor, um jovem doutor, que passaria depois a ser susten- 
tado pelo próprio esposo da amada. O lado irônico na história é que Manoel galga os degraus da boa sociedade, tornando-se homem respeitável e com o título de "Barão do Engenho Queimado", vindo a morrer de tísica pulmonar. ${ }^{11} \mathrm{~A}$ imagem do traficante funde-se assim com o sentimento anti-português que se explicitaria em diferentes níveis e contextos, como no caso do movimento da Praieira, um ano antes. E foi dessa mesma imagem que muitos proprietários escravistas aproveitaram para lançar seus reclames contra aqueles que criam ser os responsáveis por lesar a economia nacional (e, diga-se também, escravista). As páginas d'O Philantropo, em novembro do mesmo ano, citavam uma carta enviada por um proprietário de escravos e terras da Bahia que caracterizava, por sua ótica, os males trazidos pelo traficante:

A compra de africanos se tem tornado hoje entre nós um vício, cuja alimentação faz apenas enriquecer um limitado número de indivíduos degenerados cristãos, e pela maior parte estrangeiros, que devendo antes gozar da hospitalidade do país, capricham, pelo contrário, com a negligência das autoridades a reduzir esta bela terra à Costa d'África, e arruína o lavrador, pelo excessivo preço; porque os compra sem esperança de poder pagá-los. Não pode haver quem de boa fé se não convença de que esta província (Bahia), na posição que vai tomando, se tornará antes pátria de africanos do que de brasileiros, e de que apresenta hoje um vulcão, sobre o qual se acha fundado o Império! (O Philantropo, 2.11.1849)

A opinião de um escravista estampada no jornal aponta uma adequação importante que ocorria naquele momento, como já a historiografia havia demonstrado, quando todos os males ligados à escravidão poderiam ser catalisados na figura do introdutor, e menos na do consumidor de escravos.

O periódico, entretanto, pretendia ir além da crítica ao tráfico, tecendo vários argumentos contrários ao sistema escravista, ligando assim o término daquele comércio internacional ao fim gradativo da escravidão. Diversas vertentes de crítica podem ser encontradas nos textos publicados, muitas das quais estavam baseadas no antiescravismo de fins do século XVIII, ${ }^{12}$ e ora se direcionavam para o apelo à moral e à religião, por motivos humanitários, ora retomavam a justificativa econômica, considerando que tal sistema de trabalho gerava mais perdas do que ganhos quando comparado ao uso da mão-deobra livre. Um dos principais autores publicados pelo jornal foi Frederico Leopoldo César Burlamarque, cuja Memória analítica acerca do comércio de escravos, escrita em 1837, seria reproduzida n'O Philantropo. É interessante ainda ressaltar que o opúsculo de Burlamarque foi publicado logo após o fim 
da Sociedade Defensora da Liberdade e Independência Nacional, fundada por Evaristo da Veiga em 1831, organização que serviu de apoio aos liberais e que sustentava o fim do tráfico. $\mathrm{O}$ autor, segundo Conrad, viria em nome daquela sociedade, defendendo assim a causa liberal. Em 1837, para se contrapor à publicação de Burlamarque, os conservadores reeditavam o escrito de Domingos Alves Branco Muniz Barreto, Memória sobre a abolição do comércio de escravos, publicado pela primeira vez em 1817, em defesa da continuação do tráfico. ${ }^{13}$

O texto de Burlamarque repercute suas afinidades com o programa d'O Philantropo e da Sociedade contra o Tráfico: o problema está na introdução do infame comércio feita pelos portugueses; na insegurança gerada pela entrada de um sem-número de africanos; no atraso econômico que a escravidão suscita; na sua contradição com os preceitos da religião cristã; em sua nociva influência sobre os bons costumes; na má qualificação do trabalho escravo, por ser o cativo ignorante e incapaz; nas vantagens do trabalhador livre; e, por fim, nos entraves que a escravidão cria para a formação de uma nação. A escravidão, diz, é "anti-social”, mas adverte que esse mal não poderia ser suprimido de uma hora para outra:

Que a abolição deve ser lenta, é evidente; se o contrário se intentasse o país se arruinaria, sem que os próprios libertados ganhassem muito. Para emancipar os escravos sem seu prejuízo e da sociedade, cumpre fazê-los primeiramente dignos da liberdade, convertendo-os gradualmente de simples máquinas em homens ativos, ilustrados quanto possa ser, e laboriosos. ${ }^{14}$

A Memória analítica continha as principais diretrizes do programa defendido por O Philantropo e pela Sociedade contra o Tráfico, e não resta dúvida de que parte do emancipacionismo que se delinearia nas duas décadas posteriores, na proposição da Lei do Ventre Livre, ainda se fixaria no mesmo conjunto de idéias. O programa da Sociedade, o Sistema de medidas adotáveis para a progressiva e total extinção do tráfico e da escravatura no Brasil, seria encaminhado para o governo imperial em 1852, assinado, entre outros, pelo seu presidente Nicolau Rodrigues França e Leite, pelo vice Caetano Alberto Soares, e pelo secretário, o próprio Burlamarque. ${ }^{15}$ A libertação do ventre da escrava estaria em um dos itens defendidos pelos sócios para o fim gradual da escravidão, tema controverso e que então seria vetado no parlamento. O projeto do deputado Silva Guimarães, que em 1850 e 1852 levantara a questão na 
Câmara, sequer seria julgado para debate por ser considerado "inconvenientíssima", na frase de João Maurício Wanderley. ${ }^{16}$

Conformar o conjunto dos trabalhadores, tanto urbanos quanto rurais, era considerado um passo anterior ao da gradual extinção do cativeiro. Parcela importante da proposta da Sociedade contra o Tráfico dedicava-se ao estabelecimento de colônias e ao seu incentivo. Não seria, assim, mero acaso o fato de que uma grande quantidade dos sócios e colaboradores d'O Philantropo estava engajada em diversos projetos de colonização, como no caso do seu presidente.

O presidente da Sociedade, Nicolau Rodrigues França e Leite, havia sido deputado pela Paraíba pelo partido liberal, e, segundo Leslie Bethell, foi o único parlamentar que, durante os debates que discutiram a decisão britânica de penetrar nos mares brasileiros para a caça de navios negreiros em 1845, colocou-se a favor dos ingleses, argumentando que a causa da interrupção do tráfico a justificava. França e Leite era um fervoroso antiescravista (Bethell, 1976, p.231), não obstante isso não o impedisse de possuir certo número de escravos em sua propriedade na Corte. ${ }^{17}$ Como alguns outros membros da Sociedade contra o Tráfico, envolvera-se com projetos de colonização, vindo a fundar uma colônia de imigrantes europeus na região do vale do rio Doce, no Espírito Santo, e na qual estava proibida a utilização do trabalho escravo. $\mathrm{Na}$ região ainda se encontravam muitos índios — os ditos "Botocudos" - ainda não assimilados e que resistiam ao processo de ocupação de suas terras, e a colônia de Francilvânia não obteve o sucesso que imaginara. Alguns dos colonos - além de um dos filhos de Nicolau - foram mortos e muitos fugiram, fazendo que França e Leite acabasse por rescindir o contrato com o governo, para a continuação do projeto, em $1859 .{ }^{18}$

Apesar da defesa de muitos ao fim da escravidão, o envolvimento de parte dos signatários da Sociedade contra o Tráfico em projetos de colonização não implicava sempre a defesa de sua incompatibilidade com o trabalho escravo. Parte dos sócios que viam a possibilidade de uma substituição gradual do trabalho cativo tendiam a uma aproximação com a forma discutida na Sociedade Auxiliadora da Indústria Nacional, visando ao preparo dos trabalhadores através do estabelecimento de escolas agrícolas. Na realidade, reconheciam os entraves àquela substituição pela desvalorização do trabalho, realizado por escravos, e com isso, indiretamente, deixavam sem solução imediata o problema do fim do sistema escravocrata. Nessa mesma lógica, tendiam a proteger a figura do proprietário. O próprio projeto de fim gradual da escravidão, defendido no Sistema de medidas, previa uma indenização pa- 
ga ao proprietário, em trabalho devido pelo nascituro libertado, até a idade de 18 anos para as mulheres e 21 para os homens.

Nessas divergências entre a defesa intransigente do fim do trabalho escravo e a do simples término do tráfico transatlântico de escravos, percebe-se a inserção variada dos membros ativos na Sociedade contra o Tráfico. Do mesmo modo, a questão da formação do povo, tal como defendiam mais radicalmente alguns através de uma perspectiva racial mais clara, parece ter sido conduzida por uma parcela diminuta de seus membros. Ao olharmos mais de perto a variedade dos agentes da Sociedade e dos assinantes do jornal, é possível compreender como tais propostas, semelhantes às discutidas em outros espaços, circulavam entre alguns grupos presentes no Rio de Janeiro naqueles anos.

\section{PERFIL DOS Sócios}

Um ano após o início de sua circulação, O Philantropo tornou-se veículo da Sociedade contra o Tráfico e Promotora da Civilização dos Indígenas, fundada em 7 de setembro de 1850. A data da fundação da Sociedade não parece em nada aleatória, ao evocar a comemoração da Independência: a escolha procurava ligar os objetivos da associação aos anseios nacionais, assumidos na questão da chamada de braços estrangeiros e da transformação da fonte de trabalho no país. Como diziam os editoriais do jornal, a Sociedade tinha como fins a cessação do tráfico, a expatriação de africanos para a África, a formulação de meios para a chamada de mão-de-obra européia, uma política de "civilização dos índios" e a formação de escolas agrícolas. A exemplo de outras sociedades, ela realizava eleições para presidente, secretário e tesoureiro, os quais seriam respectivamente Nicolau Rodrigues dos Santos França e Leite, Frederico Leopoldo César Burlamarque e Manoel Maria de Morais e Vale. Além disso, a Sociedade possuía três comissões, voltadas respectivamente ao tráfico, à colonização e à catequese dos índios.

Nota-se na nova Sociedade a grande presença de liberais, e também de membros fundadores do Instituto Histórico e Geográfico Brasileiro e da Sociedade Auxiliadora da Indústria Nacional, além de alguns títulos nobiliárquicos e figuras notórias da política, o que sugere que o movimento sustentado pelos membros teria um cunho político mais direto, em forma de crítica ao governo conservador então no poder e de pressão sobre ele. Além da relação direta com a data que comemora a Independência, é bastante sugestivo o 
fato de a Sociedade ter sido fundada três dias após a lei Eusébio de Queirós, de 4 de setembro de 1850, indicando que visava manter a pressão sobre o cumprimento da lei.

As reuniões da Sociedade contra o Tráfico ocorriam no salão da Chácara da Floresta, propriedade de França e Leite, onde ocorreram muitas reuniões do partido liberal na década anterior. Ainda assim, e defendendo uma causa que aspirava ser nacional, o jornal e a Sociedade pretendiam colocar-se acima dos interesses partidários. De fato, apesar da predominância de liberais e de um conjunto de nomes de destaque no cenário político, verifica-se a presença de uma camada urbana composta por bacharéis, doutores em ciências, médicos, militares, religiosos e comerciantes.

Muitos dos seus membros e colaboradores pertenciam a várias sociedades em comum. Além do Instituto Histórico e Geográfico e da Sociedade Auxiliadora, chama a atenção a participação, principalmente dos mais jovens, no Ginásio Brasileiro, que agregava parcela da mocidade da boa sociedade do Império. Pode-se dizer que no perfil mais geral, predominavam aqueles que tinham formação superior. Além do mais, os círculos pelos quais transitavam aqueles homens eram quase sempre os mesmos. Frederico Burlamarque, por exemplo, era diretor do Museu Nacional e membro do Instituto Histórico (IHGB) entre outras sociedades. Possuía formação em ciências matemáticas e naturais pela Escola Militar, assim como seu colega Guilherme Schüch Capanema, o qual, além de ser próximo ao imperador, fazia parte com o primeiro de comissões e associações de ciência, como a Sociedade Velosiana. Nesse mesmo grupo, encontramos outros homens ligados às ciências e às "belas letras”, como Emílio Joaquim da Silva Maia, Joaquim Caetano Fernandes Pinheiro e Joaquim Manoel de Macedo, todos ilustres membros do IHGB.

Outro aspecto que nos parece de grande interesse é o fato de o jornal ter tido como editores dois jovens doutores pela Faculdade de Medicina do Rio de Janeiro, além de uma grande participação de médicos e farmacêuticos (ver Gráfico 1). O primeiro editor foi o gaúcho Antonio José do Vale Caldre e Fião, que atuou no jornal de 1849 a 1851 . Caldre e Fião começou a trabalhar ainda criança em uma botica e tornou-se auxiliar de boticário na Santa Casa de Misericórdia do Rio Grande do Sul. Ainda muito jovem, mudou-se para a corte, e aí aderiu aos ensinamentos da homeopatia, tendo chegado a escrever um manual para uso da Escola Homeopática do Rio de Janeiro. Para concluir sua formação em medicina, Caldre e Fião defendeu tese na Faculdade de Medicina do Rio de Janeiro em 1851, na qual dissertou sobre três pontos: a qua- 
lidade das águas, a evolução espontânea e a heterogenia. Sua atuação, por exemplo, na Sociedade Auxiliadora da Indústria Nacional, publicando textos em que defendia a substituição da mão-de-obra escrava pela livre, fez parte de sua militância antiescravista. Em seus escritos na imprensa, causava fúria entre proprietários e poderosos, tendo sido obrigado, em 1852, a abandonar a redação d'O Philantropo e sair da Corte, sob ameaças de morte. ${ }^{19}$ Com efeito, Caldre e Fião voltaria à província do Rio Grande do Sul por volta de 1854, e terminaria seus dias na colônia de São Leopoldo, fundada por imigrantes alemães. Em sua trajetória, verifica-se a preocupação com a questão da colonização e o preparo das classes pobres para se tornarem trabalhadores. Na questão do emancipacionismo, segundo Múcio Teixeira, Caldre e Fião teve como companheiros França e Leite, Torres Homem, Pimenta Bueno e Nicolau Moreira - este último, um médico muito atuante na década de 1870 contra a introdução de chineses no Brasil. ${ }^{20}$ Embora o futuro marquês de São Vicente não tenha aparecido nas listas d'O Philantropo, não é difícil imaginar as afinidades de idéias entre Bueno e Caldre e Fião, quando se verifica que anos depois, em 1866, ele é que encaminharia para discussão, no Conselho de Estado, o projeto que incluía a liberdade dos nascituros.

O segundo editor, que se manteve à frente do jornal de 1851 a 1852, foi Saturnino de Souza e Oliveira, também doutor pela Faculdade de Medicina do Rio de Janeiro. N'O Philantropo, Souza e Oliveira publicou uma "Memoria sobre os meios de abolir a escravidão no Imperio do Brasil”, na qual abordava questões relacionadas ao projeto de extinção da escravidão no Brasil. Em razão das relações familiares - Saturnino de Souza e Oliveira era filho do homônimo e sobrinho do "áulico" Aureliano de Souza Coutinho -, ele certamente não estava distante dos debates políticos que o colocavam do lado dos liberais. O posicionamento pelo fim do tráfico era uma dessas facetas. O doutor Saturnino também ocupou, ao longo da vida, cargos públicos, tendo sido nomeado cônsul em Angola, lugar onde faleceu em 1871. Ambos os editores exerceram a prática médica, aliando-a com uma preocupação dirigida à medicina voltada para a higiene e as reformas sociais, e, no caso de Caldre e Fião, ao atendimento dos pobres e escravos.

Entre os profissionais médicos que assinavam o periódico, nem todos pertenciam a um mesmo grupo de formação ou a uma escola. Encontravamse desde figuras representativas da medicina oficial e da política, como Francisco de Paula Cândido e José Martins da Cruz Jobim, até um grupo de praticantes da homeopatia, como era o caso do primeiro redator do jornal da 
Sociedade. Outros homeopatas são encontrados entre os sócios, tais como Thomaz Cochrane, Domingos de Azevedo Coutinho Duque-Estrada, Brás Dias da Matta e Inácio José Malta. Da geração mais nova que também participava do Ginásio Brasileiro, encontram-se muitos recém-formados, com grande proeminência de médicos que defenderiam teses pela Faculdade de Medicina do Rio de Janeiro, em fins da década de 1840, o que evoca uma sociabilidade entre esses homens. Militares e médicos seriam as duas categorias profissionais mais presentes na lista dos sócios.

Outros da Sociedade, no entanto, eram menos graduados, tais como os comerciantes e alguns artesãos, em profissões como as de ourives e de sirgueiro. Entre os que trabalhavam no comércio, chama atenção a presença de alguns estrangeiros. Alguns nomes indicam a presença de ingleses, que ainda pode ser auferida pela participação de John Pascoe Grenfell entre os sócios correspondentes. Ao menos mais dois estrangeiros figurariam nas listas da Sociedade, um francês e um dinamarquês, este representante de uma Sociedade Germânia de colonização.

Alguns dos nomes que se encontram entre os assinantes, entretanto, atestam um perfil distinto, e dizem respeito à classe dos proprietários. Nomes como o de Gaspar Menezes de Vasconcelos Drummond - provavelmente o bacharel pela Faculdade de Direito de Olinda, filho do homônimo e proprietário de muitos escravos e terras em Pernambuco - mostram a proximidade de alguns dos simpatizantes do emancipacionismo da Sociedade contra o Tráfico com a produção baseada no trabalho cativo. Gaspar de Menezes, o pai, era coronel e dono das fazendas Água Fria, Trapiche, Anjo e Jaceru, localizadas entre Sirinhaém e rio Formoso, onde trabalhavam em 1843, segundo o cônsul britânico H. Augustus Cowper, cerca de quatrocentos escravos. Vasconcelos Drummond, pai, também ficaria conhecido pelo episódio do palhabote português que atracou com 209 africanos em Sirinhaém em 1855, já cinco anos depois da entrada em vigor da lei Eusébio. Drummond e seu outro filho, Antônio, se viram envolvidos judicialmente no caso, tendo sido o pai preso por 11 meses, antes de ser absolvido. O coronel, que era delegado na região, fora acusado de não ter dado auto de prisão ao capitão do palhabote, e de ter deixado toda a carga ser desembarcada, tendo sumido os africanos, dos quais 49 teriam sido furtados pelo seu próprio filho Antônio. $\mathrm{O}$ caso envolveu personagens importantes do governo, como Nabuco de Araújo, e as famílias influentes locais. ${ }^{21}$ Entre os participantes das reuniões da Sociedade, ainda figuram fazendeiros do Rio de Janeiro, como o filho do marquês de Lages, Ale- 
xandre Vieira de Carvalho, e um proprietário de Macacu, chamado Antonio Marques Ferreira Barbosa.

Naquele momento, essas diferentes vozes parecem ter-se unido frente às necessidades de impor o término do tráfico. Ao fim do movimento, entretanto, é possível verificar que somente alguns dos seus agentes continuaram a delinear um programa voltado à questão da emancipação gradual ou ao modo como deveria ser realizada a colonização. E na condução desse debate, subjacentemente, o que se evidenciava era a discussão do caráter racial da nação. Embora esse tema ainda não assumisse um conceito de raça definido em bases claras, é possível verificar que tal preocupação passava a ser parte de uma agenda futura sobre a questão da emancipação gradual e da colonização.

\section{DOENÇAS AFRICANAS, RAÇA E A FORMAÇÃO DO POVO}

Ao lado da defesa da colonização estrangeira, o jornal procurava apontar os males trazidos pelo emprego do trabalho escravo. No debate antiescravista que surgia no meio urbano em meados do século, os aspectos negativos da escravidão eram glosados pelo lado econômico ou religioso, e tomados como a causa da corrupção gerada no seio da sociedade. A presença do escravo traria nessa perspectiva perigos tanto morais quanto físicos. Entre as ameaças físicas, ao lado da tematização das rebeliões de escravos em regiões próximas à corte, estava ainda a das morbidades. Freqüentemente, $O$ Philantropo tratou do tema das doenças supostamente trazidas por africanos e disseminadas pelos escravos. A grande mortalidade dos escravos, que não passava despercebida aos redatores, era associada à entrada de muitas das doenças que os acometiam. Um dos maiores responsáveis por tais males era o tráfico, como acusava Saturnino de Souza e Oliveira:

Desde que os negros são importados em nossas praias, as moléstias, das quais elesabordoforam vítimas, sedesenvolvementrenósquase sempreendemicamente. Estas epidemias tanto mais funestas nos são, quanto mais quente é a estação em que eles são importados, e quanto menor zelo tem as muito censuráveis câmaras municipais no asseio das cidades, esgotamento das valas, aterro dos pântanos \&c. A cidade do Rio de Janeiro, assim como outras do litoral, tem sido e continua a ser vítima de mortíferas epidemias, das quais a maior parte foram importadas por navios negreiros. (O Philantropo, 14.03.1851) 
Ao adentrar o ano de 1850, as críticas ao tráfico propagandeadas pela imprensa procuravam associar a escravidão aos problemas de saúde pública, em particular, causados pela "epidemia reinante", ou o surto de febre amarela que assolou a Corte naquele ano. Tal associação, entretanto, menos do que um argumento decisivo para se pôr um fim ao tráfico, pode ser tomada como um motivo a mais para convencer aos leitores de que a escravidão era um mal. Ligar a escravidão e o tráfico à propagação de doenças era comum em textos que pregavam o fim do comércio negreiro, mesmo antes do surto epidêmico. Duas patologias foram abordadas dessa forma no jornal nos anos de 1849 e 1850: a sífilis e a febre amarela. O texto intitulado "A siphylis africana" foi publicado no jornal em setembro de 1849. Como idéias gerais, o autor anônimo defendia que a origem da sífilis, distintamente do que se propagava, como um mal proveniente das Américas, fora importada do continente africano, através dos navios que faziam o tráfico de escravos.

O debate sobre a origem da sífilis era controverso e de longa data, mas começava-se a formular no Brasil, a partir de uma perspectiva que visava exaltar a benignidade do clima nacional, uma interpretação que negava que a doença teria chegado à Europa através do contato com o continente americano. ${ }^{22}$ Diga-se de passagem que a benignidade do clima brasileiro era bandeira importante na chamada de imigrantes europeus. O texto publicado n'O Philantropo não só contestava a versão de que os espanhóis teriam trazido a doença para a Europa após chegarem do Caribe, como diversos médicos defendiam - entre eles Xavier Sigaud, autor de Du Climat et de maladies $d u$ Brésil (1844) - , como afirmava que ela teria sido contraída no comércio negreiro. Prova disso seriam as fazendas repletas de escravos africanos, onde se observavam "todas as moléstias gálicas", tais como as sarnas, as pústulas malignas, os fígados bravos, o mal-de-são-lázaro e a tísica. Acusava o autor que tempos antes, no Rio de Janeiro, eram raras as tísicas tuberculosas, e que estas só se desenvolveram depois que aumentaram as reuniões do Valongo, onde se vendiam os escravos. A tuberculose era entendida como uma manifestação da própria sífilis. O texto ainda destaca de forma enfática a associação entre a sífilis e a elefantíase-dos-gregos ou lepra — o mal-de-são-lázaro —, indicando que a causa da doença também estava imbricada à idéia de "mal" e castigo por crimes morais (O Philantropo, 7.09.1849). Desta maneira, através da estigmatização era possível associar a doença à prática do tráfico.

Não obstante a ameaça das doenças ser pregada por aqueles que visavam o fim do tráfico, alguns da classe médica pareciam corroborar tais idéias, co- 
mo o médico Joaquim José da Silva. A sífilis poderia ser sintomatologicamente identificada com diversas outras doenças epidérmicas como a elefantíase e a lepra - doenças que, para o médico Silva, vinham ligadas a uma origem africana. Em sua tese Algumas considerações sobre a elefantiase dos gregos, de 1847, defendia ele que a doença teria sido transmitida ao Brasil através do tráfico negreiro. O autor afirmava que

A diminuição crescente da elefantíase no Brasil, depois que se impediu o ingresso dos africanos com a repressão do tráfico, evidentemente mostra que era da África ... que nos vinham os germens deste mal. O que ainda afirma mais esta verdade é o fato de jamais um indígena sofrer a morféia, se não tem cruzado a sua raça principalmente com os negros. ${ }^{23}$

A associação entre o tráfico e doenças ainda seria mais enfaticamente explorada no caso da febre amarela. A primeira grande epidemia de febre amarela registrada no século XIX acometeu diversos pontos do Brasil, em particular, Salvador e Rio de Janeiro. Diversos artigos são encontrados em referência a ela ao longo do ano de 1850 . Um deles, intitulado "Os contrabandistas de carne humana e a epidemia reinante" acusava o tráfico africano como causa principal da doença na cidade, moléstia que seria "uma febre da África, bem caracterizada pelos seus vômitos pretos". No texto publicado em 31 de maio de 1850, o jornal advertia sobre o caso de um vapor de guerra inglês que, em 1846, teria sido infectado por uma febre "maligna e contagiosa" após ter estado na Costa da África, insinuando que tal enfermidade contagiosa seria a febre amarela. Assim como o vapor inglês que havia contraído febre, teriam sido infectados os navios que aportaram na Bahia, em fins de 1849, supostamente envolvidos no tráfico. De lá, a doença levada por embarcações de escravos teria se espraiado para o Rio de Janeiro, que até então se mantivera imune a esse mal exógeno. Tal idéia insistia na vulgarização já corrente da representação benévola do clima do Brasil, além de culpar o tráfico pela epidemia. O Philantropo ainda se basearia em teses médicas que acusavam o tráfico de escravos como a causa da febre amarela. Esta era a opinião do médico militar francês Mathieu François Maxence Audouard, que observara a doença em Barcelona em 1821, e que acreditava que o mal provinha dos navios negreiros, em razão das péssimas condições higiênicas, gerado através dos dejetos dos cativos, os quais se impregnavam durante longo tempo nos comboios das embarcações. Sidney Chalhoub já havia tratado da recepção da tese do 
médico entre os brasileiros, e chegou a comentar as divergências da comunidade médica quanto à importação da doença pelo tráfico. ${ }^{24}$ Mesmo entre os médicos que participavam da Sociedade contra o Tráfico, a teoria do médico francês não foi nenhuma unanimidade. É certo que Francisco de Paula Cândido, assinante d'O Philantropo, chegou a defender a ligação entre tráfico e epidemia no Parlamento quando fez parte da Junta de Higiene. Porém, outros não a apoiaram, como no caso de Luiz Carlos Saules, jovem médico, membro da Sociedade contra o Tráfico e redator da Gazeta dos Hospitais. Baseado no trabalho do médico José Pinto de Azeredo Ensaios sobre algumas enfermidades de Angola, de 1799, Saules afirmou que as duas enfermidades, a febre que assolava a costa do Brasil e a febre remitente de Angola, eram distintas, e que tudo o que então se sabia era que o mal havia chegado através de um navio, que atracara na Bahia (Gazeta dos Hospitaes, 15.06.1850). Tais considerações mostram que, no momento em que a cidade era castigada pela alta mortalidade pela febre, não havia um senso comum sobre a opinião de Audouard, o que nos impede de crer que o argumento fosse determinante para o debate sobre o fim do tráfico.

O discurso dos médicos sobre a questão das doenças e dos males trazidos por africanos e descendentes mostrava-se muitas vezes ambíguo, e perpassava a questão racial de forma indireta, sem um conceito preciso de raça, não obstante isso não significasse neutralidade. Particularmente, tendo em vista a presença de uma parcela considerável de formados em medicina, torna-se interessante verificar como a discussão sobre raça que despontava nos debates do jornal se relacionava com a tradição intelectual e médica da primeira metade do século XIX no Brasil. Como estudos apontam, em geral, a tradição médica brasileira pouco enfatizou a temática racial, seja na abordagem direta do tema da raça, seja pela assunção indireta de teorias racialistas. ${ }^{25}$

Ao lado da causa humanitária que a Sociedade contra o Tráfico defendia, visando "provar ao mundo que existem homens ilustrados que abominam a escravidão", observa-se que o combate à escravidão não só era justificado como uma "ação filantrópica" - como indicava o próprio nome do jornal como também se acrescia a um vivo debate sobre as raças. Em $1^{\circ}$ de junho de 1849, o jornal afirmava: "Nós julgamos que o cruzamento das raças é uma anomalia orgânica da humanidade; e que ao contrário a sua separação se coaduna com a ordem natural das cousas". A convivência entre diferentes raças era apontada como um problema, uma vez que "as raças conservando como separadas com seus costumes e prejuízos, se aborrecem mais ou menos, e 
contrariam o espírito nacional, única condição do poder e força de uma nação". Na composição da futura nação do Império, acreditava-se que as "raças encruzadas" no Brasil eram "mal que convém sofrer por algum tempo".

Ora, tais afirmações, escritas provavelmente por Caldre e Fião, não deixam de causar certa surpresa quando observamos os discursos sobre raças e miscigenação predominantes ainda por volta de 1850. A idéia de que o "cruzamento das raças" era funesto ainda não costumava ser a opinião geralmente defendida por naturalistas e médicos brasileiros da primeira metade do século XIX. O atributo de "raça" sempre apresentou ambigüidades em seus significados, mas na primeira metade do século XIX, prevalecia a noção de um coletivo de origem comum, com um sentido equivalente ao de "nação". Foi no decorrer do século XIX que a "raça" passou a adquirir um forte essencialismo biológico, através do desenvolvimento de diferentes campos das ciências. ${ }^{26} \mathrm{O}$ desenvolvimento do conceito de "raça", no entanto, não foi homogêneo, e não teve as mesmas dimensões em diferentes tradições científicas. A centralidade de uma noção essencialista de "raça" para um ou outro grupo científico se torna mais nítida nas posturas assumidas pelos defensores do monogenismo ou do poligenismo. Os primeiros, ao defenderem que o tronco da humanidade era um só, tendiam a tornar a questão das diferenças físicas como um derivado de distintas condições externas à própria constituição dos indivíduos. Já os poligenistas defendiam uma diferença intrínseca entre os tipos humanos, pois as raças representariam a prova da criação em separado de espécies diferentes de homens. Tal debate, que envolveria uma parcela de etnólogos, zoólogos e médicos da primeira metade do século XIX, não parece ter criado grande impacto no Brasil desse período, sendo muito raras, ou mesmo inexistentes, as manifestações a favor das teorias poligenistas. Embora o jornal não se declarasse a favor da teoria poligenista, seus debates sobre o fim do tráfico e os projetos de substituição da mão-de-obra escrava acabavam ganhando um aporte próximo a ela, ao explicitarem mais enfaticamente a relação entre a "nação brasileira" e a "racialização" que perpassava o problema do trabalho livre. É possível dizer que o termo "raça”" presente n’O Philantropo acabava assim por envolver uma atitude pessimista criada pela própria ciência do período, no que concerne aos estudos dos povos não-europeus. ${ }^{27}$

No mesmo texto de Caldre e Fião, expunha-se que das duas perspectivas possíveis sobre a origem do homem, a naturalista, para a qual seriam as distinções entre as raças somente acidentais, e a doutrina mística, a qual defendia existirem povos condenados pelo pecado, era a segunda a assumida pelo re- 
dator. Sua defesa de um "povo homogêneo" calcava-se ao mesmo tempo em uma noção racial que despontava em alguns discursos científicos do momento, e em uma perspectiva bíblica sobre a condenação de alguns povos. Tais assertivas, no entanto, estavam lado a lado com opiniões como a de Saturnino de Souza Oliveira, para quem "a raça negra é tão suscetível de cultura como as outras" não obstante considerasse igualmente que o cruzamento de raças era um "mal horrível” (O Philantropo, 14.03.1851).

Outra sinalização importante dessa premissa racial está ligada a uma das causas defendidas por $O$ Philantropo, ao promover a reemigração dos africanos e seus descendentes para um território adquirido pelo Brasil na África, na tentativa de copiar o modelo da "American Colonization Society" nos Estados Unidos. Essa perspectiva mostrava que o estatuto dos africanos livres ou libertos passava a ser visto como um problema vinculado ao da formação do povo e de sua homogeneidade racial. No caso norte-americano, o movimento para a reemigração dos africanos e descendentes desenvolveu-se nas primeiras décadas do século XIX, embora a idéia de deportação dos negros já existisse desde 1714. Apesar de diversos debates ao longo de cem anos para a retirada de escravos libertos do território dos Estados Unidos, somente em 1815 Paul Cuffe tomaria a iniciativa de levar 38 libertos para a costa oeste da África. Esse marco dava início ao projeto real de criação de um estado na África formado por ex-escravos, e que passou a ser levado a cabo pela "American Society for Colonizing the Free People of Color of the United States". Formada por membros influentes reunidos em Washington, a sociedade mais tarde assumiria o nome de "American Colonization Society". ${ }^{28}$ A população liberta foi tomada pelos seus membros como perigosa e como causadora da degeneração moral da sociedade, não só para os cidadãos livres como também para os cativos. Misturando um fundo "filantrópico" que visava melhorar as condições dos ex-escravos e seus descendentes e a aversão racista à sua inclusão na comunidade republicana, a "American Colonization Society" fundou a Libéria em terras adquiridas pelo governo americano no continente africano.

No Brasil, no momento em que se atingiu o auge da entrada de africanos, O Philantropo discutia a possibilidade de estabelecer uma colônia na costa da África como uma via para o que seus editoriais chamavam de "moralização das raças". Esse projeto, no entanto, não foi incorporado no "Sistema de medidas" que a Sociedade contra o Tráfico viria a apresentar em 1852 ao governo, o que indica tanto a impossibilidade de sua viabilização como, muito provavelmente, a falta de unanimidade entre os sócios sobre essa idéia. 
Para os redatores do jornal, entretanto, a formação do povo não implicava apenas o afastamento dos africanos e seus descendentes. Diziam eles que "deixando de ser africanistas", não se deveria desejar ser "portugueses, franceses, alemães, ou qualquer outra nação". "Não nos convém", continuavam, "impedindo o tráfico da Costa d'Africa, que nos lancemos nos braços de qualquer outra nação, porque nossa nacionalidade desaparecerá inteiramente”. Ao mesmo tempo em que era preciso segregar negros e indígenas, diziam, era preciso promover a "confusão de raças" entre os colonos europeus chegados ao Brasil. A causa da colonização levada pelos membros da Sociedade visava assim estabelecer as bases daquela nacionalidade, a qual deveria agora, e de forma mais nítida, ser definida por exclusões e restrições étnicas. Por esse mesmo motivo, os indígenas que precisavam ser "civilizados" deveriam permanecer separados da mescla, como explicavam. Desta forma, a colonização que promoviam deixava de estabelecer a continuidade com as propostas secularmente defendidas de assimilação dos índios dos sertões, promovendo o casamento com brancos, para a formação da massa populacional do Império, como ainda era possível encontrar na proposta de José Bonifácio, de 1823, “Apontamentos para a civilização dos índios bravos". Na década de 1840, a redefinição do que deveria ser a colonização se impunha por palavras como a do senador Luis Dantas de Barros Leite, que não por acaso era signatário do jornal e participante da Sociedade contra o Tráfico. Em 1846, declarava ele:

No reino animal há raças perdidas; parece que a raça índia, por um efeito de sua organização física, não podendo progredir no meio da civilização, está condenada a esse fatal desfecho. Há animais que só podem viver, e produzir no meio das trevas; e se os levam para a presença da luz, ou morrem, ou desaparecem. Da mesma sorte, entre as diversas raças humanas, o índio parece ter uma organização incompatível com a civilisação. ${ }^{29}$

O discurso dá a entender que a idéia de "raça" nele presente, fincada em imagens da natureza, já seria muito próxima da condenação de povos nãobrancos praticada por alguns cientistas do período. Os redatores e colaboradores d'O Philantropo não assumiram diretamente uma noção de raça sob essas bases. Muito provavelmente, os médicos presentes no jornal se mantiveram à parte dos debates raciais como os travados por médicos norte-americanos, como Josiah Nott - um dos autores de Types of Mankind (1854), juntamente com George Gliddon e Louis Agassiz -, ou, se os conheciam, não os 
endossavam. Ainda assim, pode-se dizer que o semanário representa um ponto de inflexão nas discussões sobre a imigração e a formação do povo.

Apesar da vida breve do jornal, suas idéias reverberariam de diversas maneiras nas proposições para a nação seguidas ao longo da segunda metade do século XIX. Até quase a derrocada do Império, as políticas empenhadas para o fim gradativo da escravidão se baseariam nos mesmos princípios e nas proposições levantadas pela Sociedade contra o Tráfico. Através do jornal é perceptível como a imposição de uma leitura racial sobre os debates sobre colonização e imigração começava a se delinear nas décadas de 1840 e 1850, vindo a se integrar, já em fins do século XIX e na primeira metade do XX, à idéia de uma nação superposta à unidade étnica e lingüística - e que no caso do Brasil, era somada à da necessidade do branqueamento. ${ }^{30} \mathrm{O}$ Philantropo mostra assim uma intrigante face dos agentes que contribuíram para a difusão do entrelaçamento cada vez mais forte entre as noções de raça e nação.

\section{Gráfico 1}

Categorias profissionais e/ou de formação dos sócios da Sociedade contra o Tráfico e Promotora da Civilização dos Índios

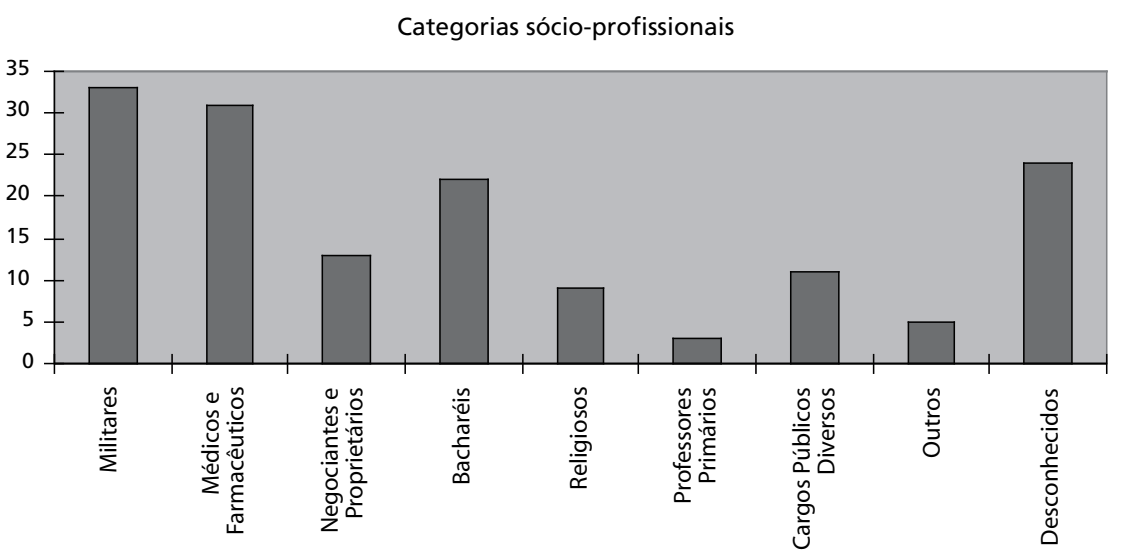

\section{NOTAS}

${ }^{1}$ Este artigo foi elaborado no âmbito do projeto "Médicos e imprensa na constituição do debate sobre as raças no Brasil-Império: o caso d'O Philantropo (1849-1852)", tendo recebido bolsa de Pesquisador Visitante da Fiocruz/Faperj.

${ }^{2}$ Nelson Werneck Sodré comenta a respeito desse jornal que ele teria "antecipado" na dé- 
cada de 1850 o movimento abolicionista dos anos 70 e 80. SODRÉ, Nelson Werneck. História da imprensa no Brasil. 3.ed. São Paulo: Martins Fontes, 1983. Entre outros, Ilmar R. Mattos também situa o jornal em meio aos movimentos de crítica e de combate aos traficantes de escravos, no contexto da promulgação da lei de extinção do tráfico negreiro, em 1850. MATTOS, Ilmar R. O Tempo Saquarema. Rio de Janeiro: Access, 1994.

${ }^{3}$ BETHELL, Leslie. A abolição do tráfico de escravos no Brasil. São Paulo: Ed. Expressão e Cultura; Edusp, 1976. p.96.

${ }^{4}$ ELTIS, David. Economic growth and the ending of the transatlantic slave trade. Oxford: Oxford University Press, 1987. p.115. Na obra de Bethell, a correspondência cita somente dois jornais que teriam recebido subsídio, O Monarchista e O Contemporaneo. (v. Bethell, 1976, p.96).

${ }^{5}$ Ver SOUZA, Christiane Laidler. Nação e Nacionalismo na Imprensa do Rio de Janeiro de 1808 a 1850. Série Estudos, Rio de Janeiro: Iuperj, v.102, p.3-49, mar. 1999 (brochura); e LIMA, Ivana Stolze. Cores, marcas e falas: sentidos da mestiçagem no Império do Brasil. Rio de Janeiro: Arquivo Nacional, 2003. Cremos que tais trabalhos contribuem para situar o periódico em um novo contexto de discussão, no qual emerge como questão a "formação do povo".

${ }^{6}$ Almanack Administrativo Mercantil e Comercial da Corte e da Provincia do Rio de Janeiro para o Anno de 1853. Rio de Janeiro: Tipografia Eduardo e Henrique Laemmert, 1853. p.328.

${ }^{7}$ Não se trata, no entanto, de discutir aqui um primum mobile para o encaminhamento do fim do tráfico. A pressão decisiva da Inglaterra é discutida em trabalhos clássicos como o de Leslie Bethell (1976). Ilmar R. de Mattos havia argumentado na década de 1980 que a condução da lei para o fim do tráfico revelava-se principalmente como fruto da direção saquarema, ao impor ao problema da escravidão a questão da soberania, tanto externa quanto interna. Assim, não só a ação inglesa fora elemento fundamental para o fim do tráfico, mas também as pressões dentro do próprio Império do Brasil, pela necessidade política de se conduzir habilmente a questão da segurança interna, gerada pelo medo das insurreições escravas (MATTOS, 1994, p.210-219). Ainda quanto à atuação inglesa, podemos mencionar a propaganda contra o tráfico sustentada pelos representantes britânicos angariando opositores brasileiros (ver ELTIS, 1987). A presença britânica age em conjunto com outras pressões, de caráter interno, manifestadas no cotidiano surdo da violência e das rebeliões de escravos. A historiografia recente sobre escravidão redimensiona o papel das revoltas escravas contra a opressão e o medo gerado pela entrada de muitos africanos logo após a proibição de 1831 . Uma série de trabalhos poderiam ser listados, mas nos ateremos ao problema do debate na imprensa.

${ }^{8}$ Ver, por exemplo, as diferentes propostas sobre o fim do tráfico e de projetos sobre reforma do escravismo em RODRIGUES, Jaime. O infame comércio. São Paulo: Ed. Unicamp, 2000. p.70. 
9 Todavia, o estatuto do que seriam esses "colonos africanos" não parece ser definido como o que viria a ser entendido como "colonização" mais tarde, associada ao caráter livre do trabalho. Diria Elói Pessoa: "Três meios se apresentão conjuntamente não só para suprir a falta de braços cauzada pela gradual extincção do Trafico, como que para povoar e engrandecer convenientemente o Brazil: $1^{\circ}$ ) a civilisação dos Indios; $2^{\circ}$ ) a colonisação dos Europeos, $3^{\circ}$ ) a colonisação dos pretos da Costa Occidental da África”. SILVA, José Elói Pessoa. Memoria sobre a escravatura e projecto de colonisação dos europeus e pretos da África no Imperio do Brazil. Rio de Janeiro: Typ. Plancher, 1826. p.19.

${ }^{10}$ O Philantropo, 20.04.1849. De fato, O Monarchista pouco discute em suas páginas a questão do tráfico como estampa as frases de sua folha de rosto, e se detém basicamente nas acusações aos luzias - os "catucás" - e na incompetência administrativa do partido liberal durante os cinco anos em que esteve à frente do governo. O Monarchista, 08.05.1849.

${ }^{11}$ O Beija-Flor, 14.04.1849.

${ }^{12}$ Sobre o antiescravismo na América portuguesa, ver ROCHA, A. Penalves. Idéias antiescravistas da Ilustração na sociedade escravista brasileira. Revista brasileira de história, São Paulo, v.20, n.39, p.43-79, 2000. Ver ainda SLENES, R. African Abrahams, Lucretias and Men of Sorrows: Allegory and allusion in the Brazilian Anti-slavery Lithographs (18271835) of Johann Moritz Rugendas. Slavery and abolition, v.23, n.2, p.147-168, 2002.

${ }^{13}$ Ver CONRAD, R. Tumbeiros: o tráfico de escravos para o Brasil. Trad. Elvira Serapicos. São Paulo: Brasiliense, 1985. p.109.

${ }^{14}$ Burlamarque, F. L. C. Memória analytica à cerca do commercio d'escravos e à cerca dos malles da escravidão doméstica. Rio de Janeiro: Typographia Commercial Fluminense, 1837. p.95.

${ }^{15}$ Sistema de medidas adotáveis para a progressiva e total extinção do tráfico e da escravatura no Brasil. Confeccionado e aprovado pela Sociedade contra o Tráfico e Promotora da Colonização e da Civilização dos Indígenas. Rio de Janeiro: Typografia do Philantropo, Rua da Assembléia n 30, 1852.

${ }^{16}$ Citado em CARVALHO, José Murilo de. Teatro de sombras. Rio de Janeiro: Ed. UFRJ; Relume Dumará, 1996. p.280.

${ }^{17}$ Nas guias de sepultamento do Cemitério São Francisco Xavier, existentes na Santa Casa de Misericórdia, consta que um escravo de França e Leite, de nome Vicente, morreu de hepato-gastro-enterite na Chácara da Floresta. Arquivos da Santa Casa de Misericórdia, Guia 1147 - Cemitério de S. Francisco Xavier, 2.09.1855.

${ }^{18}$ França e Leite tinha uma vasta quantidade de terras na região do rio Doce que foram em parte tomadas pelo governo em razão da falência do seu projeto de colonização. Arquivo Nacional, Fundo Conselho de Estado - códice 49, v.4, p.387-394. 
${ }^{19}$ Cf. TEIXEIRA, Mucio. Caldre e Fião. Revista de homeopatia, São Paulo, v.5, n.53, p.443448, 1940. p.445.

${ }^{20}$ V. LIMA, Silvio Cezar de Souza. Determinismo biológico e imigração chinesa em Nicolau Moreira (1870-1890). Rio de Janeiro, 2005. Dissertação (Mestrado) - Fiocruz.

${ }^{21} \mathrm{O}$ relato de Cowper sobre o coronel Drummond está em CONRAD, Robert E. Children of god's fire. 3.ed. Philadelphia: Penn State Press, 2006. p.72. O episódio de Sirinhaém, no qual o então ministro da Justiça Nabuco de Araújo participaria como o mandante da prisão de Drummond, ainda que este tenha sido absolvido, está relatado em NABUCO, Joaquim. Um estadista do Império. v.1. 5.ed. Rio de Janeiro: Topbooks, 1997. p.220-228. Sobre o papel dos poderes locais no fim do tráfico, ver ainda a respeito RODRIGUES, 2000, p.158-163.

${ }^{22}$ Ver a respeito CARRARA, S. A geopolítica simbólica da sífilis: um ensaio de antropologia histórica. História, ciências, saúde - Manguinhos, Rio de Janeiro, v.3, n.3, p.391408, 1996.

${ }^{23}$ SILVA, Joaquim José da. Algumas considerações sobre a elefantiase dos gregos. Rio de Janeiro: Typografia do Arquivo Medico Brasileiro, 1847. p.6.

${ }^{24}$ CHALHOUB, Sidney. The politics of disease control: yellow fever and race in nineteenth century Rio de Janeiro. Journal of Latin American Studies, v.25, p.444-463, 1993; e CHALHOUB, Sidney. Cidade febril. São Paulo: Companhia das Letras, 1993. p.68-78.

${ }^{25}$ SHEPPARD, Dalila de Sousa. A literatura médica brasileira sobre a peste branca: 18701940. História, ciências, saúde - Manguinhos, Rio de Janeiro, v.8, n.1, p.173-192, 2001. Sobre a tradição médica higienista que privilegiou a intervenção pública sobre os problemas sanitários, retirando a ênfase sobre o problema racial, ver FERREIRA, Luiz Otávio. Os periódicos médicos e a invenção de uma agenda sanitária para o Brasil (1827-1843). História, ciências, saúde - Manguinhos, Rio de Janeiro, v.11, n.2, jul.-out. 1999, p.331-351. Ver ainda suas continuidades com os sanitaristas do século XX, em MAIO, Marcos Chor. Raça, doença e saúde pública no Brasil: um debate sobre o pensamento higienista do século XIX. In: MONTEIRO, Simone (Org.) Etnicidade na América Latina: um debate sobre raça, saúde e direitos reprodutivos. Rio de Janeiro: Ed. Fiocruz, 2004. p.15-45; e LIMA, Nísia Trindade; HOCHMAN, Gilberto. Condenado pela raça, absolvido pela medicina: o Brasil descoberto pelo movimento sanitarista da Primeira República. In: MAIO, Marcos Chor; SANTOS, Ricardo Ventura. Raça, ciência e sociedade. Rio de Janeiro: Ed. Fiocruz; CCBB, 1995. p.23-40.

${ }^{26}$ Ver, entre outros, BANTON, Michael. The idiom of race. In: BACK, Les; SOLOMOS, John. Theories of race and racism. London \& New York: Routledge, 2000. p.51-63. ODOM, Herbert H. Generalizations on race in nineteenth-century physical anthropology. Isis, v.58, n.1 (Spring, 1967), p.4-18; e BLANCKAERT, Claude. On the Origins of French Ethnology. In: STOCKING Jr., George W. (Ed.) Bones, bodies, behavior: essays on biological anthropology. London: University of Wisconsin Press, 1988. p.18-55. 
${ }^{27}$ STOCKING, G. Victorian anthropology. New York: The Free Press, 1991.

${ }^{28}$ Ver SHERWOOD, Henry N. The formation of the American Colonization Society". The Journal of Negro History, v.2, n.3, July, 1917, p.209-228; e STREIFFORD, David M. The American Colonization Society: an application of republican ideology to early antebellum reform. The Journal of Southern History, v.45, n.2, May, 1979, p.201-222.

${ }^{29}$ Leite, citado em MOREIRA NETO, Carlos de Araújo. Índios da Amazônia: de maioria a minoria (1750-1850). Petrópolis (RJ): Vozes, 1988. p.337.

${ }^{30}$ SEYFERTH, Giralda. Construindo a nação: hierarquias raciais e o papel do racismo na política de imigração e colonização. In: MAIO \& SANTOS, 1995, p.41-57.

Artigo recebido em junho de 2008. Aprovado em setembro de 2008. 